\title{
Amoxicillin Loaded Magnetic Nanoparticles Developed For Treatment of Osteomyelitis
}

\section{Osteomyelit Tedavisi İçin Geliştirilen Amoksisilin Yüklü Manyetik Nanopartiküller}

\author{
Güliz Ak*๑, Tülay Yılmaz Şengel ${ }^{\circledR}$, Şenay Hamarat Şanlıer ${ }^{\circledR}$
}

Department of Biochemistry, Faculty of Science, Ege University, Izmir, Turkey.

\section{ABSTRACT}

O steomyelitis is a bone infection caused by microorganisms. Localized efficient drug delivery for treatment osteomyelitis is an important topic. Amoxicillin is one of the antibiotics used for osteomyelitis therapy. Magnetic nanoparticles could achieve localized targeted treatment with the help of magnetic field. Starch is a biodegradable and biocompatible biopolymer and can be used for carrier material for drug delivery. The aim of this study is to develop amoxicillin loaded magnetic nanoparticles for the use of treatment of osteomyelitis. Here, magnetite nanostructures were coated with starch and characterized with FTIR, TGA and SEM. It was seen that nanoparticles were spherical and had a size of 14-36 nm. Amoxicillin loading onto magnetic nanoparticles was performed by adsorption method using various concentrations of drug and 0.483 mg amoxicillin was adsorbed on per mg of nanoparticles. In addition, in vitro drug release at $\mathrm{pH} 7.4 \mathrm{was}$ obtained as in a controlled manner. As a conclusion, it can be suggested that amoxicillin loaded these nanoparticles could have a potential for drug delivery to osteomyelitis.

\section{Key Words}

Magnetic nanoparticles, amoxicillin, drug delivery, osteomyelitis.

\section{öz}

\begin{abstract}
O steomyelit mikroorganizmların sebep olduğu bir kemik enfeksiyonudur. Osteomyelit tedavisinde ilacın etkili bir şekilde lokalize gönderimi önemli bir konudur. Amoksisilin osteomyelit terapisinde kullanılan antibiyotiklerden biridir. Manyetik nanopartiküller manyetik alan yardımıyla lokalize hedefli tedavi sağlayabilmektedir. Nişasta biyoparçalanır ve biyouyumlu bir polimerdir ve ilaç gönderimi amacıyla taşıyıcı materyal olarak kullanılabilmektedir. Bu çalışmanın amacı osteomyelit tedavisinde kullanılmak için amoksisilin yüklü manyetik nanopartiküller hazırlanmaktır. Burada, magnetit nanoyapılar nişasta ila kaplanarak FTIR, TGA ve SEM ile karakterize edildi. Nanopartiküllerin küresel yapıda olduğu ve boyutlarının 14-36 nm olarak değiştiği belirlendi. Amoksisilin değişen konsatrasyonları kullanılarak manyetik nanopartiküllere adsorpsiyon metoduyla yüklendi ve maksimum olarak mg nanopartikül başına $0.483 \mathrm{mg}$ amoksisilin adsorbe edildi. Ayrıca in vitro ilaç salımının $\mathrm{pH}$ 7.4'te kontrollü olarak gerçekleştiği gözlendi. Sonuç olarak, amoksisilin yüklü manyetik nanopartiküllerin ostemyelit tedavisine yönelik olarak ilaç gönderim potansiyeli olduğu düşünülmektedir.
\end{abstract}

\section{Anahtar Kelimeler}

Manyetik nanopartiküller, amoksisilin, ilaç gönderimi, osteomyelit. 


\section{INTRODUCTION}

N anoparticles, submicrometersized particles, can consist of a number of materials, including polymers, metals, and ceramics. Magnetic nanoparticles are generally biodegradable and considered to have low toxicity. Potential benefit of using magnetic nanoparticles is the use of localized magnetic field gradients to concentrate the particles. Iron oxide nanoparticles, as magnetic nanoparticles, are suitable for the performance in diagnostics as contrast agents (magnetic resonance imaging), in pharmacology as drug carriers (site specific drug delivery etc.) and have unique superparamagnetic properties. Magnetite (Fe3O4) is one of the iron oxide nanoparticle used in biomedicine. [1-3]. Thanks to these advantages magnetic nanoparticles enable magnetic targeted therapy for diseases.

Pure iron oxide nanoparticles have large hydrophobic surface could lead to the removal from circulation due to increase in particle size. When they functionalized or coated with hydrophilic surface they are removed from circulation much slower owing to gaining ionic or steric stabilization [2]. Polymers and other surfactants have been used for stabilization problems. Starch, is composed of repeating 1,4- $\alpha$-D glucopyranosyl units: amylose and amylopectin, is one of the strong hydrophilic and biodegradable polymers and can also be used functionalization of magnetic nanoparticles [4].

Osteomyelitis is an inflammatory process accompanied by bone destruction and caused by an infecting microorganism (mostly Staphylococcus aureus) The various types of disease require differing medical and surgical therapeutic strategies. Unfortunately, the high success rates of antimicrobial therapy in most infectious diseases have not yet been achieved in bone and joint infections [5]. Infection therapies could be failure because of antimicrobial resistance, location of many pathogens in an active or latent state and the lack of novel drugs. Nanoparticles offer alternative strategies (high drug loading capacity, facilitation of movement of drug, reaching target area, acrossing the osteoblast membrane, better drug delivery to intracellular bacteria, decreasing side effects and etc.) for overcoming those problems [6]. There are some papers about osteomyelitis therapy using various drug loaded nanoparticles $[7,8]$ Amoxicillin is a broad spectrum, bacteriolytic $\beta$-lactam antibiotic and it is used to treat bacterial infections (for instance osteomyelitis [9]). Despite better absorption following oral administration, its usage has substantially reduced since many of the pathogens have become resistant to it [10]. Therefore, carrying with nanoplatforms could be beneficial to increase its action.

In this work, starch coated magnetic nanoparticles were prepared and the evidence of structure was evaluated with FTIR and TGA analyzes. SEM obervations also characterized the particles. A wide spectrum antibiotic, amoxicillin, was chosen for osteomyelitis treatment drug and amoxicillin was loaded on nanoparticles with high ratio. Drug release demonstrated controlled profile which was usually preferred during therapy. Those magnetic nanoparticles could enable magnetically targeted therapy.

\section{MATERIALS and METHODS}

\section{Materials}

Starch was purchased from Merck; folin reagent (FCR) was bought from Fluka, sodium hydroxide $(\mathrm{NaOH})$ and sodium carbonate $\left(\mathrm{Na}_{2} \mathrm{CO}_{3}\right)$ were obtained from Sigma Aldrich. Amoxicillin (AMOX) was a kind gift from Deva Holding A.Ş. All the other reagents were analytical grade.

\section{Synthesis of Starch Coated Magnetic Nanoparticles}

Magnetite nanoparticles were previously synthesized according to our method [11]. Starch coated magnetic nanoparticles was prepared based on the modification of a study written by Kim et al. [12]. Starch (3\%, w/v) was dissolved in $80 \mathrm{~mL}$ of distilled water at $80^{\circ} \mathrm{C}$ with constant stirring. After that starch solution was set in water bath at $60^{\circ} \mathrm{C}$. Magnetite nanoparticles $(50 \mathrm{mg} /$ $\mathrm{mL}$ ) were dispersed using ultrasonic bath and poured into starch solution drop by drop with stirring at 750 rpm. Then $0.1 \mathrm{M} \mathrm{NaOH}$ solution was added dropwise into the mixture until $\mathrm{pH}$ was nearly 11 and the mixture was stirred at $60^{\circ} \mathrm{C}$ for $2 \mathrm{~h}$. After that it was cooled to room temperature and allowed to stand for $12 \mathrm{~h}$ for gelation. The gels were washed with $\mathrm{d}$-water until the $\mathrm{pH}$ was about neutral. Starch coated magnetic nanoparticles was dried in drying oven at $60^{\circ} \mathrm{C}$ for drug loading and characterization tests.

\section{Characterization}

For chemical analyzes, magnetic nanoparticles were investigated with Fourier transform infrared spectroscopy (FTIR, Perkin Elmer FTIR Spectrum One-B Spectrometer) and thermogravimetry (TGA, Perkin Elmer Diamond 
TG/DTA). Potassium bromide pellets were prepared for FTIR tests and samples were heated from room tempareture to $600^{\circ} \mathrm{C}$ in a nitrogen atmosphere for TGA. In addition nanoparticles (without Au coating) were examined with scanning electron microscope (SEM, Philips XL-30S FEG and FEI Quanta250 FEG) in Izmir Institute of Technology in order to observe the morphology and size. For all tests dried form of nanoparticles were used.

\section{Spectrophotometric Determination of Amoxicillin}

Determination of amoxicillin was performed using the modification of the method described by Singh and Maheshwari [13]. Briefly, sodium carbonate solution $(2.5 \mathrm{~mL}, 10 \% \mathrm{w} / \mathrm{v})$ was added into each AMOX solution, tubes were placed in a water bath maintained at $98^{\circ} \mathrm{C}$ for $40 \mathrm{~min}$, then cooled to room temperature. FCR (3.5 $\mathrm{mL}$ ) was added to each tubes and the final volume was adjusted to $10 \mathrm{~mL}$ with d-water. Absorption of blue coloured-solutions were dedected spectrophotometrically (Perkin Elmer Lambda 35) at $\lambda_{\max } 720 \mathrm{~nm}$. For standard curve $2-30 \mu \mathrm{g} / \mathrm{ml}$ of AMOX (aq) solutions were used and calculations for drug loading onto nanoparticles were carried out based on this equation $(y=0.0309 x$, $\left.R^{2}=0.9958\right)$.

\section{Adsorption of Amoxicillin on Magnetic Nanoparticles}

In this study, amoxicillin was loaded onto starch coated magnetic nanoparticles (NP) with adsorption technique according to a study [14]. $10 \mathrm{mg}$ of starch coated nanoparticles were dispersed in drug solution at 0.25; $0.5 ; 0.75 ; 1 ; 1.5 ; 2 \mathrm{mg} / \mathrm{mL}$ of AMOX solution. The mixtures were incubated at $37^{\circ} \mathrm{C}$ for $24 \mathrm{~h}$ then centrifuged at $13.000 \mathrm{rpm}$. Samples were washed and centrifuged again. Supernatants (unbound drug samples) were collected and measured for AMOX determination spectrophotometrically. AMOX adsorption yield and and adsorbed drug amount were calculated using these formula (1) and (2) below, respectively.

Drug loading efficiency $(\%)=$ $\underline{\text { Initial AMOX amount }(\mathrm{mg})-A M O X \text { amount in supernatant }(\mathrm{mg})} \times 100$ Initial AMOX amount $(\mathrm{mg})$

Adsorbed drug amount $\left(\frac{m g A M O X}{m g N P}\right)=$ Initial AMOX amount $(\mathrm{mg})-$ AMOX amount in supernatant $(\mathrm{mg})$ Weight of nanoparticles $(\mathrm{mg})$

\section{In vitro AMOX Release Study}

In vitro drug release of AMOX from nanoparticles were carried out utilizing dialysis membrane tubing method [15]. Drug loaded nanoparticles were dispersed in phosphate buffer $\mathrm{pH} 7.4$ and transferred into dialysis tubing (MWCO $=12.000$, Sigma Aldrich). Tubing was placed in $20 \mathrm{~mL}$ of buffer and set into water bath at $37^{\circ} \mathrm{C}$ for 5 h. Samples were taken at predetermined time intervals and analyzed for AMOX content. Released amount of AMOX was measured and relative drug release (\%) was calculated.

\section{RESULTS and DISCUSSION}

\section{Synthesis of Starch Coated Magnetic Nanoparticles and Characterization}

Polymers have been used to modify and cover the magntite nanoparticles in order to enhance their stability [16]. In this study starch was chosen for coating material. It was thought that this biopolymer could prevent the aggregation of $\mathrm{Fe}_{3} \mathrm{O}_{4}$ structures. Coating was achieved in alkaline medium due to interactions of hydroxyl groups. FTIR and TGA analyzes were carried out to check the structure of starch coated magnetic nanoparticles. Figure 1 shows FTIR spectra of magnetite nanoparticles and starch coated magnetic nanoparticles. The broad signal at $3400 \mathrm{~cm}^{-1}$ was ascribed to $\mathrm{OH}$ streching and the peak at $580 \mathrm{~cm}^{-1}$ corresponded to Fe-O bond. These signals were found both pure magnetite and starch coated nanoparticles. The new bands were seen in FTIR spectrum of the coated nanoparticles. The band at 1151 $\mathrm{cm}^{-1}$ was attributed to $\mathrm{C}-\mathrm{O}$ streching of the $\mathrm{C}-\mathrm{O}-\mathrm{H}$ group and the peaks at $1078 \mathrm{~cm}^{-1}$ and $1023 \mathrm{~cm}^{-1}$ corresponded to $\mathrm{C}-\mathrm{O}$ streching of the $\mathrm{C}-\mathrm{O}-\mathrm{C}$ group in glucose rings of the starch [16]. Those findings were verified starch coating of magnetite nanoparticles.

TGA analyzes of free magnetic nanoparticles and starchcoated magnetic nanoparticles were seen in Figure 2. The weight loss of samples depend on temperature clearly showed that there was an organic layer (10\%) in the structure of coated nanoparticles. While at a ratio of only $2 \%$ (corresponded to adsorbed water layer) was lost in pure magnetite, $10 \%$ of the weight (except for water layer) was lost until $600^{\circ} \mathrm{C}$. It was known that magnetite protects its structure till $600^{\circ} \mathrm{C}$ [17]. Therefore it can be said that magnetite was coated with starch successfully.

SEM images of starch coated magnetic nanoparticles 
140 | G. Ak et al. / Hacettepe J. Biol. \& Chem., 2020, 48 (2), 137-145
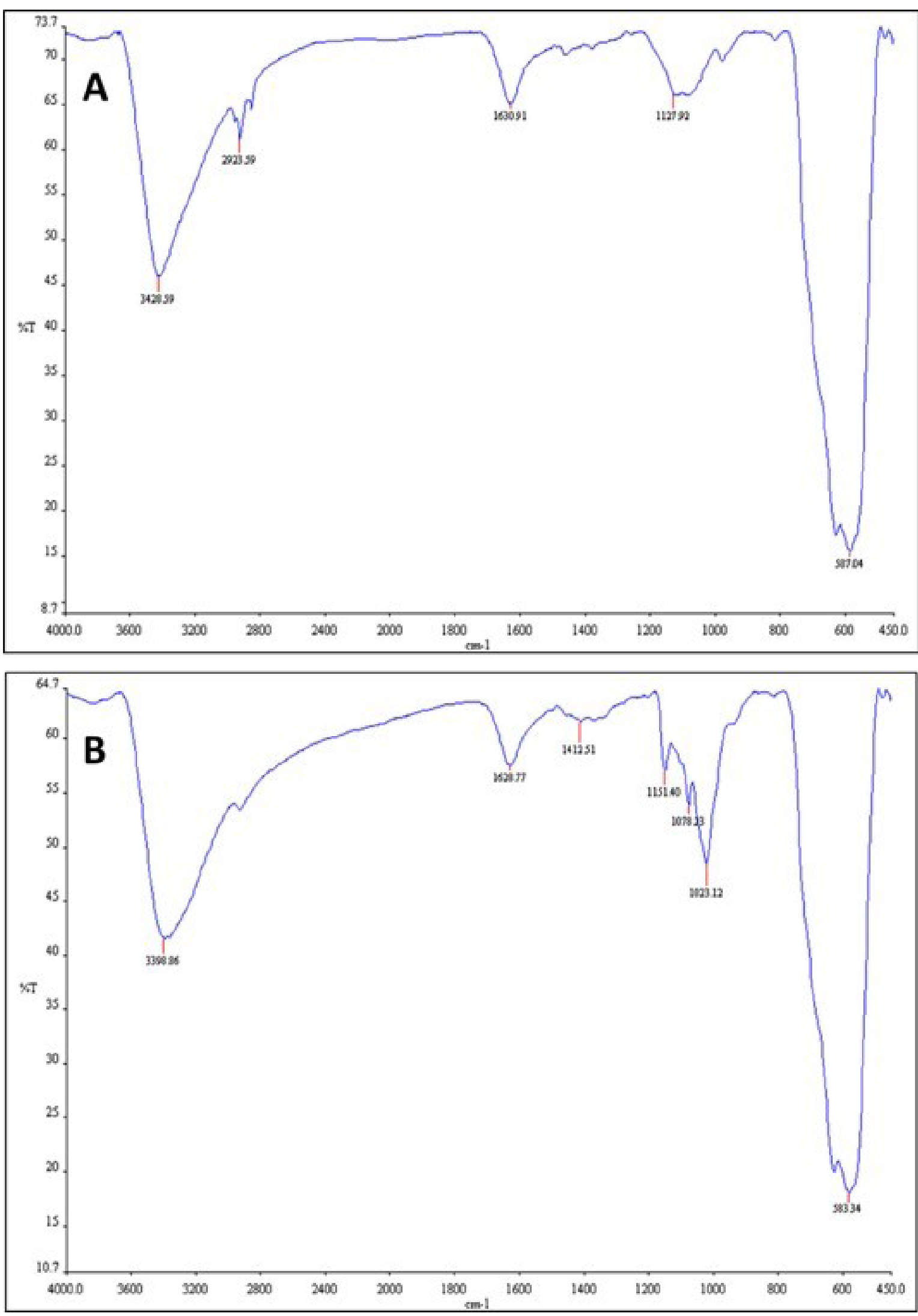

Figure 1. FTIR spectra of A) pure magnetite and B) starch coated magnetic nanoparticles. 

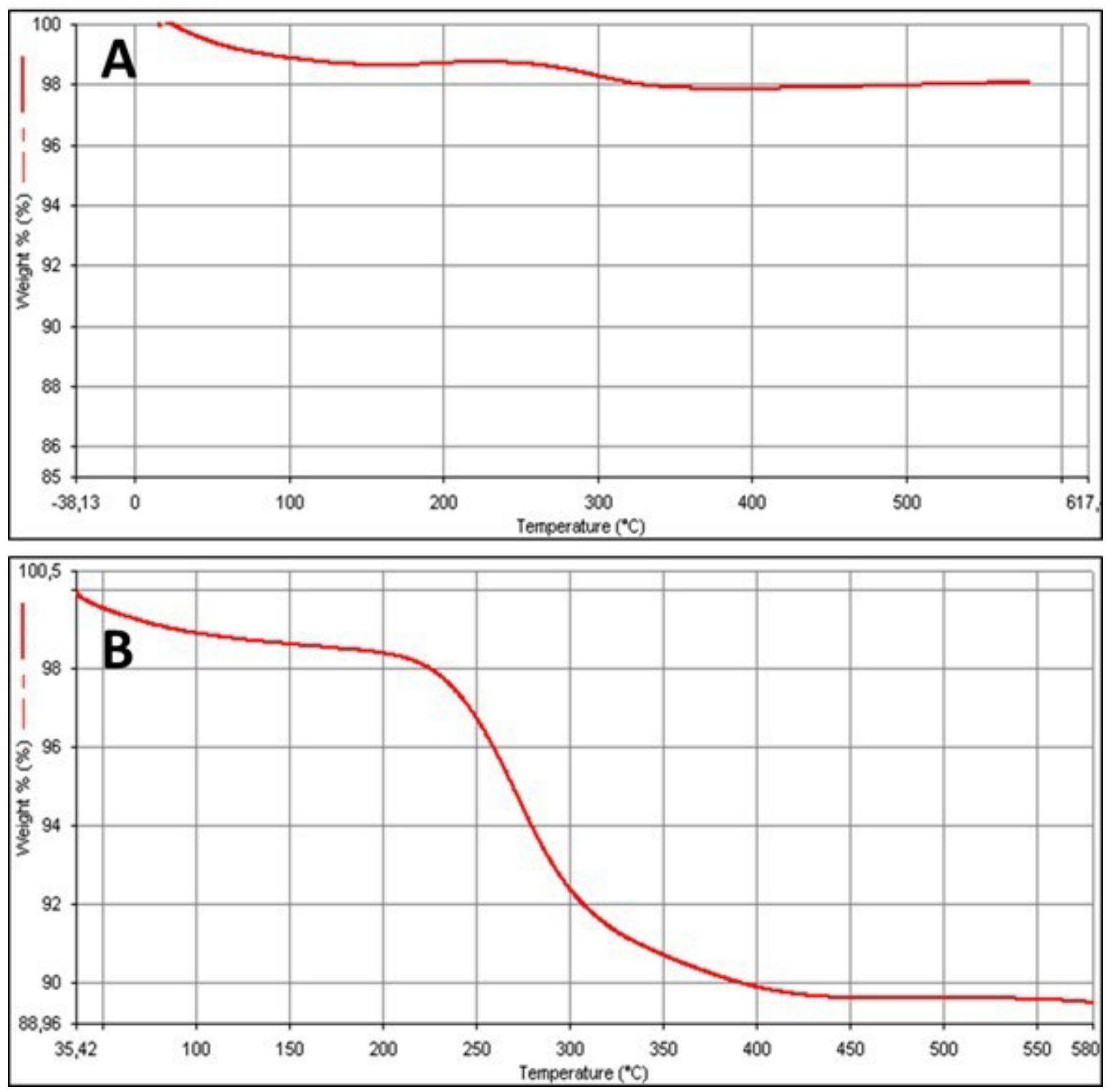

Figure 2. Themogram curves of A) pure magnetite and B) starch coated magnetic nanoparticles.

were illustrated in Figure 3. Although coating process significantly affects the particle size [18], obtained structures were spherical in shape and had a size of 14-36 nm. Similar results were found in other studies [17-18].

\section{Adsorption of Amoxicillin on Magnetic Nanoparticles}

After the characterization tests amoxicillin, an penicilin based-antibiotic, was loaded onto starch coated magnetic nanoparticles by adsorption method. Effective factors in adsorption are electrical attraction, van der Waals interactions and chemical bonds. Chemical and/ or physical interactions were thought to be responsible for binding of starch coated magnetic nanoparticles bet- ween amoxicillin. Drug adsorption yield and adsorbed drug amount versus increased drug concentration were demonstrated in Figure 4. Adsorption yields of AMOX were determined as nearly same as 95-99\%. In accordance with increasing drug concentrations adsorbed drug amount increased and $0.483 \mathrm{mg}$ amoxicillin was adsorbed on per mg of nanoparticles when $2 \mathrm{mg} / \mathrm{mL}$ initial AMOX concentration was used. Thus, concentration of $2 \mathrm{mg} / \mathrm{mL}$ was selected as optimum initial drug dose.

\section{In vitro AMOX Release Study}

AMOX release from nanoparticles was studied in physiological $\mathrm{pH}(7.4)$ in order to imitate normal tissue and circulation and at $37^{\circ} \mathrm{C}$ so as to stimulate body temperature. Release 


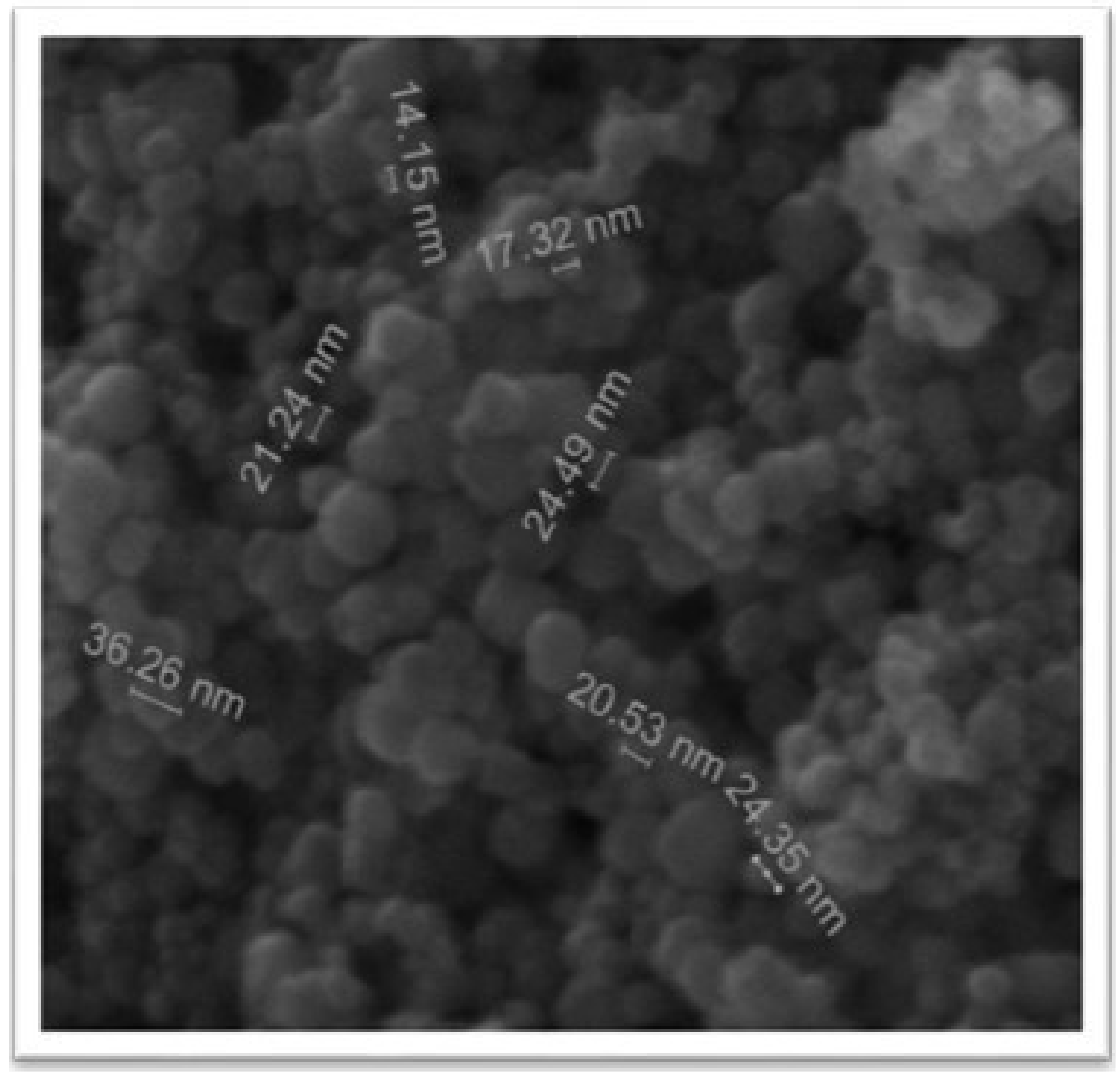

Figure 3. SEM images of starch coated magnetic nanoparticles.

profile of drug was shown in Figure 5. It was seen that there was sustained release of AMOX. Release percent was $18.5 \%$ at $30 \mathrm{~min}$, $48.7 \%$ at $1.5 \mathrm{~h}$ and $72.5 \%$ at $5 \mathrm{~h}$. In the other words, amoxicillin release from nanoparticles was occured in controlled manner. In a study AMOX release from polyacrylic acid and chitosan copolymer compositions (PAA:CS:A, 1:2.5:2) was suitable with sustained manner and release was found as about $25 \%$ at 20 min at 60\% at $1.5 \mathrm{~h}$ in acidic medium [19]. It is thought that AMOX release would be accelerate in infectious site of osteomyelitis.
As a conclusion, it is suggested that amoxicillin loaded nanoparticles promising magnetically targeted and localized drug delivery for osteomyelitis treatment as well as other infections therapy.

\section{Acknowledgments}

The authors thank the Scientific and Technological Research Council of Turkey, TUBITAK (2209-A) for funding of this study. 

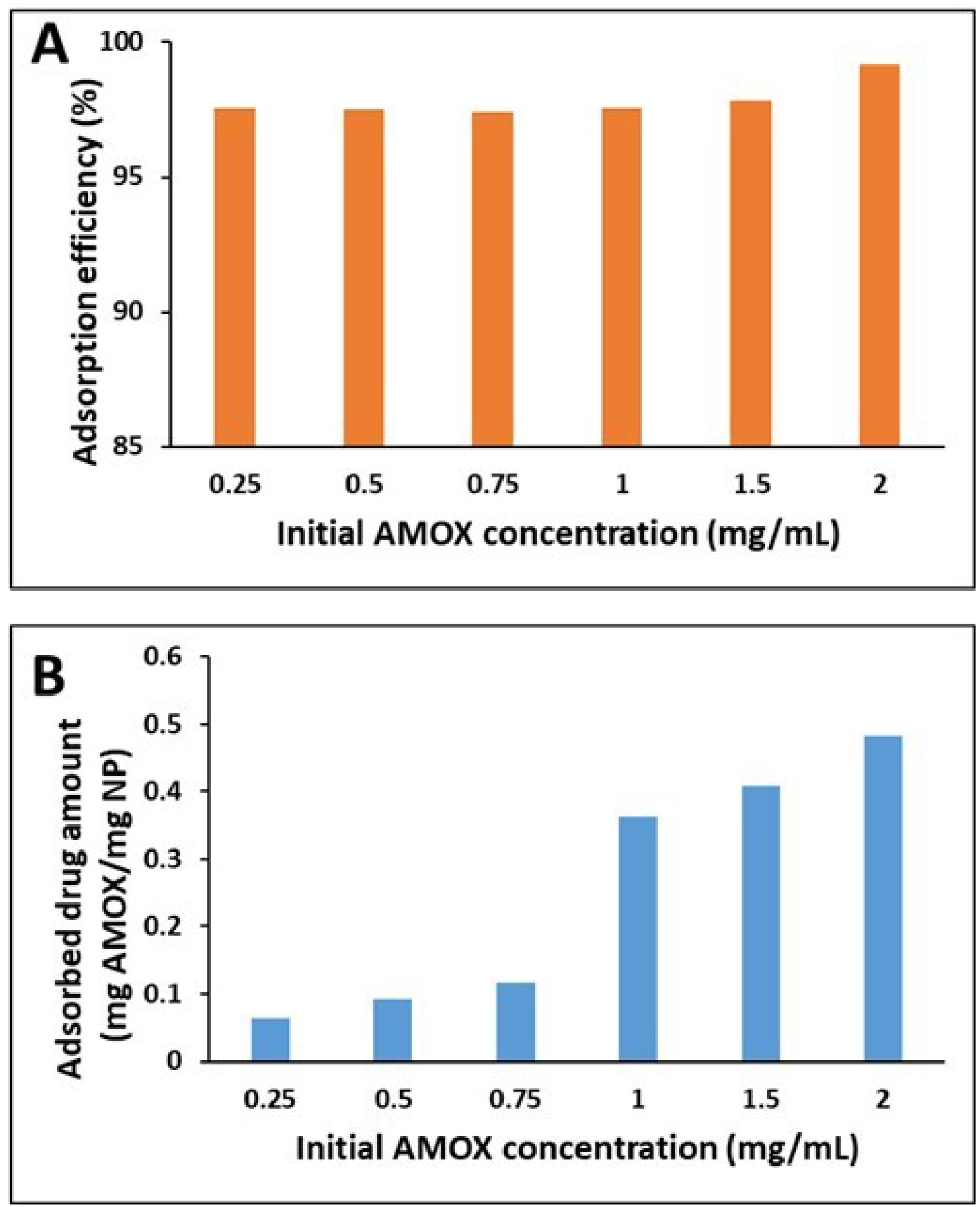

Figure 4. Adsorption yield (\%) and adorbed amonut of AMOX (mg AMOX/ mg NP) onto nanoparticles. 


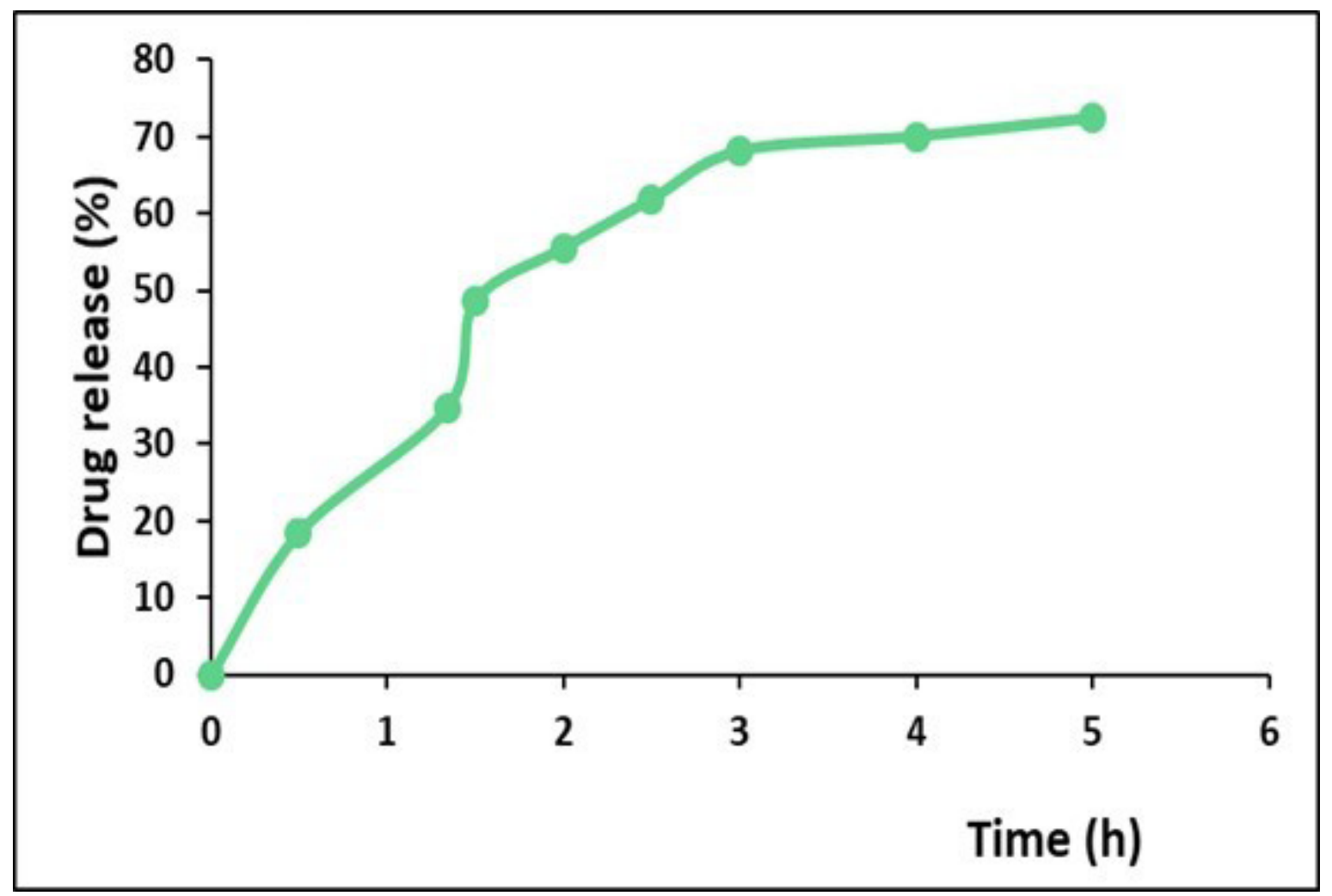

Figure 5. AMOX release (\%) from nanoparticles at pH 7.4 phosphate buffer.

\section{References}

1. X. Wang, L. Yang, Z. Chen, D.M. Shin, Application of nanotechnology in cancer therapy and imaging. CA: a cancer journal for clinicians, 58 (2008) 97-110.

2. P. Martinkova, M. Brtnicky, J. Kynicky, M. Pohanka, Iron Oxide Nanoparticles: Innovative Tool in Cancer Diagnosis and Therapy. Advanced healthcare materials, 7 (2018) 1700932.

3. M.R. Saboktakin, A. Maharramov, M.A. Ramazanov, Synthesis and characterization of superparamagnetic nanoparticles coated with carboxymethyl starch (CMS) for magnetic resonance imaging technique. Carbohydrate polymers, 78 (2009) 292-295.

4. T.T. Dung, T.M. Danh, L.T.M. Hoa, D.M. Chien, N.H. Duc, Structural and magnetic properties of starch-coated magnetite nanoparticles. Journal of Experimental Nanoscience, 4 (2009) 259-267.

5. D.P. Lew, F.A. Waldvogel, Osteomyelitis. The Lancet, 364 (2004) 369-379.

6. H. Zazo, C.I. Colino, C. I., J.M. Lanao, Current applications of nanoparticles in infectious diseases. Journal of Controlled Release, 224 (2016) 86-102.

7. R.R. Pillai, S.N. Somayaji, M. Rabinovich, M.C. Hudson, K.E. Gonsalves, Nafcillin-loaded PLGA nanoparticles for treatment of osteomyelitis. Biomedical Materials, 3 (2008) 034114.
8. U. Posadowska, M. Brzychczy-Wloch, E. Pamula, Injectable gellan gum-based nanoparticles-loaded system for the local delivery of vancomycin in osteomyelitis treatment. Journal of Materials Science: Materials in Medicine, 27 (2016) 9.

9. H.S. Fraimow, Systemic antimicrobial therapy in osteomyelitis. In Seminars in plastic surgery, 23 (2009) 90.

10. S.Y. Gbedema, F. Adu, M.T. Bayor, K. Annan, J.S. Boateng, Enhancement of antibacterial activity of amoxicillin by some Ghanaian medicinal plant extracts. International Journal of Pharma Sciences and Research, 1 (2010)145-152.

11. Ş.H. Şanlıer, G. Ak, H. Yılmaz, A. Ünal, Ü.F. Bozkaya, G. Tanıyan, Y. Yildirim, G.Y. Türkyılmaz, Development of UltrasoundTriggered and Magnetic-Targeted Nanobubble System for Dual-Drug Delivery. Journal of Pharmaceutical Sciences, https://doi.org/10.1016/j.xphs.2018.10.030, (2018) In Press.

12. D.H. Kim, K.N. Kim, K.M. Kim, Y.K. Lee, Targeting to carcinoma cells with chitosan- and starch-coated magnetic nanoparticles for magnetic hyperthermia. Journal of Biomedical Materials Research - Part A, 88 (2009) 1-11.

13. D.K. Singh, G. Maheshwari, Spectrophotometric determination of penicillins in pure and pharmaceutical formulations using Folin-Ciocalteu reagent. Drug testing and analysis, 2 (2010) 503-506

14. H. Yılmaz, S.H. Sanlıer, Preparation of magnetic gelatin nanoparticles and investigating the possible use as chemotherapeutic agent. Artificial cells, nanomedicine, and biotechnology, 41 (2013) 69-77. 
15. G. Ak, H. Yılmaz, S.H. Sanlıer, Preparation of magnetically responsive albumin nanospheres and in vitro drug release studies. Artificial cells, nanomedicine, and biotechnology, 42 (2014) 18-26.

16. P.R. Chang, J. Yu, X. Ma, D.P. Anderson, Polysaccharides as stabilizers for the synthesis of magnetic nanoparticles. Carbohydrate polymers, 83 (2011) 640-644.

17. K. Petcharoen, A. Sirivat, Synthesis and characterization of magnetite nanoparticles via the chemical co-precipitation method. Mater Sci Eng B., 177 (2012) 421-427.
18. R.Y. Hong, B. Feng, L.L. Chen, G.H. Liu, H.Z. Li, Y. Zheng, D.G. Wei, Synthesis, characterization and MRI application of dextran-coated Fe3O4 magnetic nanoparticles. Biochemical Engineering Journal, 42 (2008) 290-300.

19. M. Paloma, S. Torrado, S. Torrado, Interpolymer complexes of poly (acrylic acid) and chitosan: influence of the ionic hydrogel-forming medium. Biomaterials, 24 (2003)14591468. 